\title{
Diagnostic Contribution of Postmortem Needle Biopsies in Neonates
}

\section{Yenidoğanlarda Postmortem İğne Biyopsisi Sonuçlarının Klinik Tanılara Katkısı}

\author{
Özgü Suna CELILOĞLU', Can CELILOĞLU1', Erdal KURNAZ², Ramazan ÖZDEMiR², Ahmet KARADAĞ²
}

Department of Children's Health and Diseases, 'Adana Kozan State Hospital, ADANA, TÜRKIYE, 'inönü University, Faculty of Medicine, MALATYA, TURKEY

\begin{abstract}
Objective: We examined the contribution of neonatal postmortem needle biopsy in circumstances of autopsy denial where magnetic resonance imaging cannot be performed.
\end{abstract}

Material and Method: 247 postmortem needle biopsy specimens of 76 neonatal cases who died in the neonatal intensive care ward of a tertiary hospital between 2005 and 2010 and where the family did not give permission for an autopsy were retrospectively evaluated.

Results: 90 needle biopsy attempts (36.4\%) were unsuccessful among the 247 biopsies. Liver needle biopsies were found to yield the most valuable diagnostic contribution. A total of 53 liver biopsies provided clinical information that contributed to the diagnosis.

Conclusion: The postmortem needle biopsy should be applied in all cases in which standard biopsy cannot be performed. Success rates and level of information gained by extrahepatic needle organ biopsies in neonates were found to be quite low whereas needle biopsies of the liver yielded valuable results. We believe it is more appropriate to perform percutaneous postmortem biopsies solely on the liver in neonates.

Key Words: Postmortem diagnosis, Needle biopsy, Newborn

\section{öz}

Amaç: Standart otopsinin reddedildiği ve postmortem manyetik rezonans görüntüleme yapılamayan durumlarda, sadece iğne biyopsisinin klinisyene verebileceği tanısal katkıyı araştırmayı amaçladık.

Gereç ve Yöntem: Üçüncü basamak yoğun bakım hizmeti veren bir yenidoğan yoğun bakım servisinde 2005-2010 yılları arasında ölen, ailesi tarafından otopsiye izin verilmeyen ve postmortem iğne biyopsisi yapılmış 76 yenidoğan olgunun, perkutanöz elde edilmiş 247 adet postmortem doku örneği raporları retrospektif olarak değerlendirildi.

Bulgular: 247 biyopsi girişiminden 90 tanesinde (\% 36,4) biyopsi başarısızlıkla sonuçlanmıștı. Postmortem iğne biyopsisi ile en başarılı klinik sonuç alınan organ karaciğerdi. Karaciğerde toplam 53 biyopsi sonucu bize ön tanıya katkı sağlayacak bilgi verdi.

Sonuç: Standart otopsinin yapılamadığı tüm durumlarda iğne ile postmortem biyopsi uygulanabilir. Yenidoğanlarda karaciğer dışı organlarda yapılan postmortem biyopsilerin başarılı olma ve tanısal bilgi verme oranları oldukça düşükken karaciğer örneklerinde tanıya katkı sağlayacak bilgiler elde edilmiştir. Bu nedenle biz yenidoğanlarda postmortem örneklemeyi sadece karaciğere yapılmasının daha uygun bir yaklaşım olacağını düşünmekteyiz.

Anahtar Sözcükler: Postmortem tanı, İğne biyopsisi, Yenidoğan

\section{INTRODUCTION}

Newborn life expectancy in Turkey is increasing with each passing year (1). According to the World Health Organization, the newborn mortality rate in Turkey has decreased from 29 per 1000 live births in 1990 to 9 per 1000 live births in 2011 (2). The postmortem evaluation of babies, especially those that have died in the newborn period without a definite diagnosis, can guide us when diagnosing possible additional pathologies not detected during their lifetime, providing prenatal counseling to the patient's family

(Turk Patoloji Derg 2013, 29:122-126)

Received : 12.01.2013 Accepted : 21.02.2013 for other pregnancies, and planning appropriate follow-up of the mother and the baby during future pregnancies. All the examinations performed after the death of a patient are within the scope of an autopsy. An autopsy is the gold standard in making a definite or previously unconsidered diagnosis (3). Postmortem autopsy is recommended to the family of each newborn following death (3). Despite the benefits of autopsy, families increasingly refuse having an autopsy done (4). Postmortem percutaneous needle biopsy examination and/or magnetic resonance imaging (MRI) alone is recommended when autopsy cannot be performed

Correspondence: Ahmet KARADAĞ

İnönü Üniversitesi Tıp Fakültesi, Çocuk Sağlığı ve Hastalıkları AD,

MALATYA, TURKEY

E-mail: ahmetkaradag@gmail.com Phone: +90 4223410660 
due to rejection by the family $(5,6,7)$. Although MRI alone provides perfect macroscopic information, it does not give microscopic information. Needle biopsy is reported to be a good alternative in the absence of an autopsy (8).

We investigated whether needle biopsy contributes to the diagnosis in cases where autopsy is refused in this study, the first on this subject in newborns in Turkey.

\section{MATERIAL and METHOD}

The reports of 247 postmortem tissue samples obtained by percutaneous $16 \mathrm{G}$ Tru-cut needle biopsy from 76 newborn cases who had died between 2005 and 2010 in our newborn intensive care service providing tertiary level newborn intensive care service and whose postmortem needle biopsies had been performed after obtaining the consent of the families were retrospectively evaluated. Brain biopsies were performed from the anterior fontanelle, lung biopsies from the intersection of the midaxillary line with the third rib, heart biopsies from the intersection of the left third intercostal space with the midclavicular line, liver biopsies from the intersection of the right midclavicular line with the sixth-seventh rib, spleen biopsies from the intersection of the left anterior axillary line with the sixth-seventh rib and renal biopsies from the intersection of the lower border of the $12^{\text {th }}$ rib with the lateral border of the quadratus lumborum muscle. Postmortem fine needle biopsies in our clinic are performed by pediatricians or by experienced senior residents who first serve at least two years as pediatric residents. Samples were fixed with $10 \%$ formaldehyde, routine tissue processing was performed, and paraffin blocks were prepared. The samples were cut in sections 5 microns thick, stained with hematoxylin-eosin and evaluated under light microscopy. We then determined whether the biopsy results provided information contributing to the diagnosis obtained from hospital records of the cases and biopsy records.

Patients were classified according to demographic characteristics such as gender, gestational week, relationship between mother and father, whether this was the first pregnancy, and mother's miscarriage history. Cases were classified according to the clinical features regarding the presence of congenital abnormalities, acidosis, hepatosplenomegaly, sepsis, and metabolic disease. They were then divided into six subgroups depending on the organ biopsied as liver, lung, spleen, brain, heart and kidney. If the biopsy taken from a planned organ was found adequate for the examination it was classified as a "successful biopsy," while if it belonged to another organ besides the target organ or was not adequate for material examination it was classified as a "failed biopsy".

Statistical analysis was performed using the SPSS 16.0.1 (SPSS Inc., Chicago, IL, USA) program. Quantitative data were presented as mean \pm standard deviation and qualitative data as numbers and percentages.

\section{RESULTS}

A total of 247 biopsy samples belonging to 76 patients whose postmortem tissue samples were obtained with a Tru-cut needle biopsy were evaluated. Cases with biopsies were divided into two groups according to gender, and into another two groups as gestational age of 37 weeks or below and gestational age over 37 weeks (Table I). Mean gestational age was consistent with 35 weeks, and the mean birth weight was $2372 \pm 380$ grams. Table I presents the distribution of the cases in terms of being born of the mother's first pregnancy and the mother's miscarriage history.

Preliminary diagnoses and/or clinical findings listed in the hospital records are shown in Table II. More than half of the patients had no prediagnosis (55.3\%). The distribution of total biopsy numbers and failed biopsy numbers by organ are shown in Table III. 90 (36.4\%) of the 247 biopsies were evaluated as unsuccessful where the tissue of the related organ was not obtained. We saw that many kidney and spleen biopsies could not be evaluated due to insufficient sample. No information that would have contributed to the present clinical diagnosis or preliminary diagnosis was found in heart, lung, and brain tissue material.

Table I: Demographic characteristics of cases

\begin{tabular}{|l|l|c|}
\hline \multirow{2}{*}{ Gender } & & Number of patients (\%) \\
\hline \multirow{2}{*}{ Gestation week } & Female & $31(40.8 \%)$ \\
\cline { 2 - 3 } & Male & $45(59.2 \%)$ \\
\hline History of relationship between the mother and the father & $<37$ th week & $42(55.2 \%)$ \\
\cline { 2 - 3 } & $>37$ week & $34(44.8 \%)$ \\
\hline History of being born of the first pregnancy of the mother & $20(26.3 \%)$ \\
\hline Miscarriage history of the mother & $22(28.9 \%)$ \\
\hline
\end{tabular}


The liver was the organ which provided the most productive results after needle biopsy. Liver tissue was obtained from $74(77.8 \%)$ of a total of 95 liver needle biopsies and various pathological information was obtained from 53 of them (Table IV). This information was listed in order of frequency as steatosis, canalicular cholestasis, inflammation and fibrosis, necrosis, iron overload, hepatitis, hemochromatosis, alpha 1 antitrypsin deficiency and total parenteral nutrition damage.

Table II: Preliminary diagnoses and/or clinical findings stated in the hospital records

\begin{tabular}{|l|c|}
\hline Preliminary diagnosis & Number of patients \\
\hline Congenital anomaly & 12 \\
\hline Acidosis & 26 \\
\hline Hepatosplenomegaly & 11 \\
\hline Sepsis & 17 \\
\hline Metabolic disease & 17 \\
\hline $\begin{array}{l}\text { Preliminary diagnosis / clinical } \\
\text { information not present }\end{array}$ & 42 \\
\hline
\end{tabular}

Table III: Number of total and unsuccessful biopsies from the organs

\begin{tabular}{|l|c|c|}
\hline & Total biopsy & Unsuccessful biopsy \\
\hline Liver & 95 & 21 \\
\hline Lung & 62 & 31 \\
\hline Brain & 62 & 20 \\
\hline Heart & 23 & 13 \\
\hline Spleen & 4 & 4 \\
\hline Kidney & 1 & 1 \\
\hline Total & 247 & 90 \\
\hline
\end{tabular}

Table IV: Pathology results of 53 liver biopsies that various pathological information was obtained

\begin{tabular}{|l|c|}
\hline Result & Biopsy Sample \\
\hline Steatosis & 17 \\
\hline Canalicular cholestasis & 12 \\
\hline Inflammation and fibrosis & 6 \\
\hline Necrosis & 6 \\
\hline Iron accumulation & 4 \\
\hline Hepatitis & 3 \\
\hline Hemochromatosis & 2 \\
\hline Alpha-1 antitrypsin deficiency & 2 \\
\hline Total parenteral nutrition damage & 1 \\
\hline
\end{tabular}

\section{DISCUSSION}

This first study investigating the consistency of postmortem biopsies with clinical preliminary diagnoses in newborns in Turkey showed that needle biopsies did not contain tissues belonging to the related organ and were unsuccessful in $36.4 \%$ of the cases. The highest number of clinical results with needle biopsies was obtained from the liver in our study. 42 (55.2\%) of our cases were premature (smaller than 37 weeks according to gestational age). A study in India found a history of prematurity in $48 \%$ of patients and other studies where most subjects were premature have also been reported (9).

An autopsy is essential as it can provide important information concerning the determination of fetal malformation and cause of death. However, autopsy rates are declining (9). The most common method used in cases where an autopsy is not allowed is postmortem needle necropsy (10). This method can be used in all cases where a full autopsy cannot be performed (9).

The advantages of postmortem needle biopsy are that tissue samples for histopathological and microbiological analysis can be obtained, samples can be taken without tissue deterioration as they are removed at the bedside, and microbiological and immunological studies can be carried out in the obtained material if necessary (10). Definite microbiological factors (nocardiosis, pneumocystis, miliary tuberculosis, etc.) were found with microbiological examination of needle aspiration biopsy material in 8 cases in a study performed on a total of 19 deaths with no diagnosis including two children (10). Other advantages of needle autopsy is that it is fast, minimally invasive, inexpensive, and more acceptable for patients' relatives. However, macroscopic examination and dissection of internal organs cannot be performed by percutaneous needle biopsy (10). The false negativity rate is also high with percutaneous needle biopsy as a localized lesion within the organ cannot be detected. Even if any lesion determined by this method may have contributed to death, it may not be the only cause of death. This method may be more helpful in the evaluation of diseases commonly affecting visceral organs such as the lung, kidney or the liver.

90 (36.4\%) of the 247 biopsies examined in our study were evaluated as unsuccessful where the tissue of the related organ was not obtained. We saw that a high number of kidney and spleen biopsies were not evaluated due to insufficient sample. No significant specific finding/diagnosis was found in biopsy materials of the heart, lung, and brain tissues. Garg et al. reported that the most successful postmortem 
needle biopsy studies in newborns were from the liver (92\%) and lung (84\%), followed by the brain, left kidney, right kidney and finally spleen, but biopsy materials did not lead to significant pathological findings (9). The most successful organ biopsies in a postmortem study on 50 patients were obtained from the lung (90\%) and liver (82\%) followed by the kidney (48\%), heart (28\%), spleen (22\%) and pancreas (18\%) (8). The most information in addition to the clinical diagnosis was obtained with liver (fatty liver in 19 cases) and lung biopsies (pneumonitis in 11 cases) in this study from India. Breeze et al. reported the most successful postmortem needle biopsy results in perinatal mortality cases to be from the lung (86\%) and liver (76\%) (11). We believe the available results indicate that needle biopsy sampling of the liver is more cost-effective than for other organs.

The most successful clinical information was obtained through postmortem needle biopsy of the liver in our study. Liver tissue was obtained from $74(77.8 \%)$ of a total of 95 biopsies and clinical information on the liver was obtained from 53 of them. Steatosis (17 cases) was most frequently seen, followed by canalicular cholestasis (12), inflammation, and fibrosis (6), necrosis (6), iron accumulation (4), hepatitis (3), hemochromatosis (2), alpha-1 antitrypsin deficiency (2), and total parenteral nutrition injury (1) in order of frequency.

Needle biopsies were fully compatible with complete autopsies in $56 \%$ and partially compatible in $12 \%$ of the cases in a study (9). New knowledge was obtained in $60 \%$ and a major diagnosis was made in $6 \%$ of the cases through autopsy in a study investigating congenital heart disease (12). We obtained additional clinical information in 53 patients (69\%) with liver biopsy. However, the additional clinical information in all 53 patients was not in the form of a new diagnosis but a contribution was made to a specific diagnosis with the support of biochemical tests in only seven patients (three hepatitis, two hemochromatosis, two alpha-1 antitrypsin deficiency). Although the liver needle biopsy results did not help reach a specific diagnosis in 46 patients although additional information was provided in addition to the clinical diagnosis or preliminary diagnosis, they emphasized a pathology that could be related to the liver-associated diagnosis. The liver in newborns is larger in proportion to the body weight (5\% of body weight) and can be easily palpated, so percutaneous needle biopsy is more likely to be successful. It seems rational that the liver is the first preferred organ for newborn postmortem sampling when the relative ease of access to the organ, the high possibility of sampling, examination convenience, and reduction of postmortem diagnostic intervention costs are considered. However, more studies are needed in this regard.

A successful spleen biopsy rate of $17 \%$ was reported by Breeze et al. and $20 \%$ by Garg et al. $(9,11)$. These results show that the spleen is the most difficult organ to perform biopsy sampling on. All splenic biopsies failed in our study. These difficulties experienced in spleen sampling should be kept in mind. According to our results, a brain biopsy was successful in $67 \%$ of the cases but no specific pathology was reported and 93\% of these brain biopsies were found to be normal. Garg et al. reported $85 \%$ of brain biopsies in their study to be successful, detecting meningitis in one case while the remaining 16 were normal (9).

This first study from Turkey on whether postmortem biopsies provide clinical information contributing to the clinical preliminary diagnosis in newborns showed that about $40 \%$ of needle biopsies did not contain a tissue sample belonging to the related organ and were unsuccessful. The liver was reported to provide the most successful needle biopsy results in our study.

We were unable to classify in detail and compare the unexpected findings according to the cause of death as our sample consisted of only 76 cases and any subgroups would each contain a very small number of biopsies. This was a retrospective study so it is limited by its adherence to the hospital records and biopsy records of the patients. We used premortem and postmortem diagnoses/findings only according to the information obtained from these sources. Our hospital is a tertiary care institution and takes care of patients with severe and complex problems so may not reflect child deaths in other hospitals and in Turkey.

This study showed that needle biopsies of the liver obtained in newborns where autopsy cannot be performed provides extra information that contributes to the clinical diagnosis or preliminary diagnosis while needle biopsies of the spleen, brain, and kidney have a low rate of success and do not provide information contributing to the clinical diagnosis / preliminary diagnosis even if successful. We therefore believe limiting needle autopsies in newborns with the liver would be a better approach and that this biopsy would contribute to the clinical diagnosis / preliminary diagnosis. 


\section{REFERENCES}

1. Demirel G, Tezel B, Ozbas S, Oguz SS, Erdeve O, Uras N, Dilmen $U$ : Rapid decrease of neonatal mortality in Turkey. Matern Child Health J 2012. [Epub ahead of print].

2. Levels \& Trends in child mortality. Report 2012. Estimates Developed by the UN Inter-agency Group for Child Mortality Estimation. UNICEF. Access: http://www.who.int/ maternal_child_adolescent/documents/levels_trends_child_ mortality_2012.pdf

3. Pavón Delgado A, Salinas Martín MV, Losada Martínez A, Fontillón-Alberdi M, Núñez Solís JM, Zamarriego Zubizarreta $C$ : Value of autopsy in a neonatal intensive care unit. An Pediatr (Barc) 2008, 69:124-128

4. Khong TY, Tanner AR: Foetal and neonatal autopsy rates and use of tissue for research: The influence of 'organ retention' controversy and new consent process. J Paediatr Child Health 2006, 42:366-369

5. Alderliesten ME, Peringa J, van der Hulst VP, Blaauwgeers $H L$, van Lith JM: Perinatal mortality: Clinical value of postmortem magnetic resonance imaging compared with autopsy in routine obstetric practice. BJOG 2003, 110:378-382

6. Brookes JA, Hall-Craggs MA, Sams VR, Lees WR: Non-invasive perinatal necropsy by magnetic resonance imaging. Lancet 1996, 348(9035):1139-1141
7. Sebire NJ: Towards the minimally invasive autopsy? Ultrasound Obstet Gynecol 2006, 28:865-867

8. Bansal MG, Punia RS, Sachdev A: Clinical and needle autopsy correlation evaluation in a tertiary care teaching hospital: A prospective study of 50 cases from the emergency department. Am J Forensic Med Pathol 2012, 33:194-196

9. Garg S, Punia RP, Basu S, Mohan H, Bal A: Comparison of needle autopsy with conventional autopsy in neonates. Fetal Pediatr Pathol 2009, 28:139-150

10. El-Reshaid W, El-Reshaid K, Madda J: Postmortem biopsies: The experience in Kuwait. Med Princ Pract 2005, 14:173-176

11. Breeze AC, Jessop FA, Whitehead AL, Set PA, Berman L, Hackett GA, Lees CC; Cambridge Post Mortem MRI Study Group: Feasibility of percutaneous organ biopsy as part of a minimally invasive perinatal autopsy. Virchows Arch 2008, 452:201-207

12. Kay MH, Moodie DS, Sterba R, Murphy DJ Jr, Rosenkranz E, Ratliff N, Homa A: The value of the autopsy in congenital heart disease. Clin Pediatr (Phila) 1991, 30:450-454 